93rd Annual Meeting

of The American Phytopathological Society

August 26, 2001, Salt Lake City, Utah

\title{
A Perspective of the Future: American Phytopathological Society
}

\author{
Steven A. Slack \\ Associate Vice President of Agricultural Administration and Director, Ohio Agricultural Research and Development Center, Ohio State \\ University, Columbus/Wooster 44691.
}

As we look to the next decade, it is clear that we face many challenges. In most cases, these challenges are not unique to our profession or professional society, the American Phytopathological Society (APS). Indeed, we have recognized that we must reach out to other professional societies who share some of the same professional and scientific needs and challenges as APS. This year we are meeting jointly with the Society of Nematologists (SON) and the Mycological Society of America (MSA). Joint symposia and paper sessions will address the need to stir scientific curiosity and enhance the exchange of ideas and perspectives. However, we must utilize our time together to think more broadly about the future-the survival—of our disciplines. Two other speakers, Mary Clutter of the National Science Foundation, and Jim MacDonald of the University of California-Davis, have addressed science funding at the national level and the opportunities and implications of electronic journals, respectively. These issues are core to our survival and to the functioning of our societies in the future. In this address, I will focus on issues that I feel will and are influencing the APS environment and that we must consciously address if we are to proactively influence the future of APS.

Trends. APS was founded in 1908 with 130 charter members. The membership has increased in each succeeding decade and now numbers about 5,000 worldwide. In the last decade, membership increases are due to increased membership outside North America. The percentage of APS membership outside the United States has increased about $10 \%$ in this period and now comprises about $31 \%$ of the membership. During this same period, APS has invested extensively in electronic delivery systems both for dissemination of scientific literature as well as of membership services and this trend will continue. Surveys indicate that persons outside the United States join APS for multiple reasons, but most indicate the desire for scientific information and for intercourse with colleagues as primary reasons. Electronic communication undoubtedly has played a role and will continue to play a role in these demographics. An important point to remember is that our demographic profile generally is changing and, consequently, the needs and expectations of our membership are changing and becoming more diverse.

Another trend is that our revenue streams increasingly are coming from nondues and nonmember sources. This is most evident when we examine the income sources for APS Press. APS Press represents $30 \%$ of the Society income, however, $80 \%$ of the revenue is from nonmember sources. This fact is a clear example of the difference in "customer" versus "member" needs. We, in fact, are meeting a goal of our strategic plan to be "a premiere re-

Publication no. P-2001-1112-020 source for plant health information and knowledge dissemination," but customer needs will not drive services and knowledgebased information like member expectations. Likewise, journal income from Phytopathology, Plant Disease, and Molecular Plant-Microbe Interactions represents $46 \%$ of our societal income. Thus, three-fourths of our income is derived from our publication and publication-related efforts. From a financial perspective, this knowledge represents the "intellectual equity" of our Society and must be treated and regarded as an asset.

These trends have substantial implications as we look to the future. They certainly must be considered as we look to maintain and enhance APS over the next decade. APS follows a strategic planning process to prioritize and focus its agenda. It is critical that the strategic plan remains a dynamic document and that our actions and progress can be monitored accordingly.

Knowledge generation and dissemination. As mentioned previously, our journals are our intellectual equity. It is critical that our journals be first-rank publications for APS to retain its place as the leading source of plant health information. A committed core of our membership dedicates considerable professional expertise annually to assure journal quality. We are also expanding opportunities to contribute to the literature and to broaden our audience base by developing and supporting electronic-based publications. Plant Health Progress is an interdisciplinary electronic journal targeted to practitioners concerned with current concepts and knowledge applicable to pest management strategies. Plant Health Instructor is a peer-reviewed electronic outlet for teaching and instructional material. These publications add two unique dimensions to our existing publication portfolio.

Knowledge must also be disseminated in other ways in order to facilitate information exchange and to enhance networking among members. The annual meeting is a primary vehicle. Recently, the organization of the annual meeting has been developed and balanced through sections (Biology of Pathogens, Diseases of Plants, Epidemiology/Ecology/Environmental Biology, Molecular/Cellular Plant Microbe Interactions, and Professionalism/Service/Outreach) with section chairs, and a Scientific Programs Board has been established to oversee and coordinate activities associated with the annual meeting, short courses, and special events such as a videoconference on an exotic pest newly discovered in the United States. Further, APSnet is increasingly being used as a delivery mechanism for information, both to make members and others aware of events and programs as well as to be able to access APS publications. These actions are not meant to be static or final, rather they must continue to evolve as member needs change.

It must be mentioned that competitive funding sources are critical to the generation of quality information. Grant programs through the National Science Foundation, National Institutes of Health, and the U.S. Department of Agriculture (National Re- 
search Initiative and Initiative for Future Agriculture and Food Systems) are critical to the health of our science. Likewise, the quality and nature of the science supported reflects on the sciencebased standing of the funding agency. This is not to diminish the equally critical funds from industry, commodity groups, and other sources. However, universities and other organizations make investment decisions (positions, infrastructure, etc.) on the basis of established and growing competitive grant programs. The ability to recruit outstanding students and research scientists to our discipline is directly related to the funding available to study exciting biological phenomena.

Sustainability. APS must leverage its assets in order to maintain itself and to keep a positive financial posture. Our ability to generate new and exciting programs and projects is directly related to our ability to fund such ventures. For at least the past 2 decades, we have a history of taking calculated financial risks to launch new ventures on a 4 to 5 year cycle, with a new investment being made about the time that our revenues again match expenditures. Examples include launching Plant Disease (formerly Plant Disease Reporter), APS Press, Molecular Plant-Microbe Interactions, and the commitment to electronic publications and communication (APSnet). These, of course, have been successful ventures and are a credit to our past leadership.

As indicated earlier, three-fourths of our income is generated from journals and APS Press. It is essential that the intellectual property represented by our publications be protected so the revenue stream is not dissipated. This will be no small task as we move to electronic distribution of our journals and the concomitant exercise to establish guidelines and maintain an equitable revenue flow with libraries and other subscribers. There is also a movement to freely share back content of journals. This may make sense under some conditions but we must determine the conditions. We receive no subsidy for our publications, they must be self-sustaining. We are in the very fortunate position of preparing our journals in-house for publication, which helps us to control our destiny. However, we will have several opportunities to utilize this "equity" in the future and careful decisions will be necessary to keep APS sustainable. Likewise, we must continue to look outward with APS Press. The financial success of APS Press is due, in part, to the fact that customers external to APS need and appreciate the products developed. Recognizing and distinguishing our efforts to reach customers as well as members will be important.

Other assets include the fact that we own our headquarters building and employ an outstanding permanent professional staff in partnership with our sister society the American Association of Cereal Chemists (AACC). AACC and APS have worked together to manage these resources and have leveraged these resources to provide support for the International Society of Molecular Plant Microbe Interactions (IS-MPMI) and the American Society of Brewing Chemists (ASBC). We are now entering into an agreement to manage the Master Brewers Association of the Americas. Each of these arrangements has its own particular history, but all match well with our core competencies. Selective decisions, which build on our competencies, can and should enhance our future stability.

Alliances and partnerships. Communication with "like-minded" societies such as SON and MSA is important to our future. A joint annual meeting makes scientific sense because we can exchange ideas and concepts and effectively enhance the networking of our members. However, these are also opportunities to share our visions and our constraints as societies. The effectiveness of how we communicate as societies may impact our futures significantly. The impact may be through gained knowledge or through collective attention to issues of mutual interest.

Participation with appropriate coalitions has become and will continue to be essential. Examples include the Council of Agricultural Science and Technology (CAST), Coalition on Funding Agricultural Research (CoFarm), American Institute of Biological Sciences (AIBS), and Council of Scientific Society Presidents (CSSP). These coalitions enable us to participate as part of a larger group on issues of importance to our members. Active participation enables us to have our views and concerns considered and expressed as part of the coalition. It is important that we carefully select the coalitions in which we participate so that they enhance our mission and strategic goals.

Internally, we must also continually evaluate how we do business in order to build and maintain our membership. Individuals join and maintain their membership for various reasons. APS uses surveys to document those reasons and the issues that are important to members. Issues may be structural (e.g., representation on boards or council) or functional (e.g., selection process for symposia at annual meetings). In many cases, answers may not be readily apparent or easily resolved, however, our ability and willingness to continue to grapple with substantive core issues will keep us flexible and growing rather than inflexible and static. As part of this process, we must also be willing to advocate for our science. This past year, the National Plant Pathology Board was reconstituted as the Public Policy Board following a committee recommendation. The Public Policy Board is comprised of our elected society leadership as well as selected leaders across our membership. This group monitors issues that are external but important to APS members. This board also utilizes the linkages established with other societies and coalitions to respond to rapidly emerging issues.

Strategic thinking. APS governance has undergone a significant transition in recent years. The transition has been to decentralize decision-making and to have leadership focus more on strategic issues that will provide guidance for the future. This transition has been evolving with APS Council, Headquarters staff, and Headquarters Operations Committee (HOC). APS Council increasingly dedicates time to considering and discussing major issues and delegates on-going activities to appropriate boards and committees. Headquarters staff functions have been reorganized such that the executive vice president increasingly spends time considering the major issues that will sustain our society rather than focusing on daily management issues. The HOC is comprised of the leadership from both APS and AACC and has historically dealt with policy issues related to operating the headquarters building. More recently, HOC has increasingly devoted time to strategic issues important to both societies. It is important that our decision makers continually strive to look ahead rather than focusing on where we are. Our future depends on our ability to do this effectively.

Summary. APS is a dynamic society. We have made excellent decisions in the past that have positioned us to deal effectively with the future. We must both nurture and leverage those assets that have sustained us so that they continue to do so. We must maintain and build alliances and partnerships, which make strategic sense, and we must continually challenge ourselves to look and think forward about society issues. I take great pride in having had the opportunity to lead such a progressive society. We should all take great pride in where our society is going collectively. 